ISSN: 2162-3104 Print/ ISSN: 2166-3750 Online

Volume 7, Issue 2 (2017), pp. 270-290

(C) Journal of International Students

http://jistudents.org/

\title{
Cross-Cultural Student Teaching: Examining the Meaning-Making of one White, Female, Middle- Class Preservice Teacher
}

\author{
Stephanie J. Shedrow \\ University of Wisconsin-Madison, USA
}

\begin{abstract}
While teacher educators implement diverse student teaching placements for preservice teachers as a means of bridging the cultural mismatch in classrooms around the United States, researchers have only recently begun to tap into the role that preservice teachers' "whiteness" plays in their ideologies. As such, the purpose of this study was to better understand how one white, female preservice teacher made meaning of her experiences during a cross-cultural experiential learning (CCEL) student teaching placement abroad. Analyzing if and how previous intercultural interactions were drawn upon while abroad, as well as how experiences abroad were employed once returning to the US, findings suggest that cultural competency does not directly equate to recognizing whiteness and the privileges associated.
\end{abstract}

Keywords: cross-cultural experiential learning, cultural mismatch, narrative inquiry, student teaching, whiteness theory

I've realized how lucky I am, though, to have been able to shape [my] educational philosophy at a university full of resources and knowledge. Most of this realization came after a few conversations with a teacher at the school, who I will call Pauline. At first, I had a shamefully inexplicable dislike for her. She was disheveled, awkward, and didn't seem to understand that I was there to observe, not to teach on my first day there. Then she told me that she too had been told the wrong information several times; she hadn't prepared for this class's lesson because she was told she'd be teaching the subject in 2 other grades. She was thrown off and desperate for my help. In later conversations, I realized that my dislike was really 
directed at the differences between us, which was unfair (Personal Communication, February, 2014).

This excerpt is from a blog posted by Nora Street, a twenty-oneyear-old preservice teacher, while conducting nine weeks of student teaching in a small farming village in western Uganda as part of a crosscultural experiential learning (CCEL) program. While cross-cultural experiential learning programs, where student teachers live and work in cultures different from their own, have become a widely accepted means of preparing preservice teachers for teaching in diverse classrooms (e.g. Alfaro \& Quezada, 2010; Batey \& Lupi, 2012; Clement and Outlaw, 2012; Cushner \& Chang, 2015; Kissock \& Richardson, 2010; Landerholm and Chacko, 2013; Lee, 2011; Lu \& Soares, 2013; Martin, 2012; Marx \& Moss, 2011; Rodriguez, 2011; Sharam, Rahaza \& Phillion, 2013; Thomas, 2012), there is a lack of empirical studies regarding how preservice teachers make meaning from these programs (Anderson \& Stillman, 2013; Cushner \& Chang, 2015). As such, the purpose of this study is to explore how preservice teachers make meaning from their experiences student teaching abroad. More specifically, it explores if, and subsequently how, these student teachers draw on previous life events when making meaning of their cross-cultural experiences.

\section{CULTURAL MISMATCH IN THE CLASSROOM}

Although K-12 classrooms around the country are becoming more and more economically and culturally diverse, teacher candidates continue to be predominantly White, middle-class women (National Center for Education Statistics, n.d.). This “demographic divide” (Gay \& Howard, 2000, p. 1) between white teachers and the students they teach results in an unequal and inadequate education for students of color (e.g. Gay, 1997; McDonald, et al., 2011; Rust, 2010), and often present career-ending challenges for novice teachers (e.g. Banks, et al., 2005; Freeman et. al, 2012; Voltz, 1998). In short, preservice and novice teachers are not prepared to work with diverse populations of students (Burbank, Ramirez \& Bates, 2012). One point of contention may be the varying value systems held by white teachers in the dominant culture and students from non-dominant cultures (Marx \& Moss, 2011; O’Connor, 1993). Sleeter (2001) even argues that most white preservice teachers have little understanding of discrimination or racism, and an almost nonexistent background in cross-cultural experiences or knowledge.

Consequently, teacher educators have realized the importance of providing opportunities for preservice teachers to recognize their own ethnocentric worldviews and cultural identities so they may, in turn, develop interculturally and come to understand and value the worldviews of their students (e.g. Banks et. al, 2005; Kennedy \& Heineke, 2016; 
McAllister \& Irvine, 2000; Marx \& Moss, 2011). One of the most common pedagogical methods that universities employ to prepare preservice teachers for work in culturally diverse schools is through a social justice oriented teacher education program (Cochran-Smith, 2010; Burbank, Ramirez \& Bates, 2012; Whipp, 2013). However, what pedagogical practices are employed under the umbrella term "teacher education for social justice” remains ambiguous (Cochran-Smith, 2010), and many researchers have noted that preservice teachers' dispositions and ideologies cannot be augmented simply by exposure to multicultural education (e.g. Conchran-Smith \& Zeichner, 2005; Grant, 1994; Wilson, Floden, FerriniMundy, 2001). In addition, it has been established that teacher education programs built around themes of social justice do not have a significant impact on actual teacher beliefs (Buehler, Ruggles, et al., 2009; Burbank, Ramirez \& Bates, 2012; Sleeter, 2001; Voltz, 1998).

Another common pedagogy utilized in teacher education programs is a programmatic requirement that preservice teachers participate in one or more service learnings, practicums, or student teaching placements in an urban or culturally diverse school (e.g. Burban, Ramirez \& Bates, 2012; Foote \& Cooke-Cottone, 2004; Green et al., 2011; Kennedy \& Heineke, 2016). However, these programs often have mixed results; while many studies have reported positive outcomes, others have indicated that the experience can actually solidify preservice teachers' predispositions and stereotypes (Anderson \& Stillman, 2013; Sleeter, 2001). Although similar in theory, CCEL placements differ from these programs in that the preservice teachers are unable to retreat to the safety of their familiar cultural groups and environments. In this way, the preservice teachers' cultural worldviews, which tend to be largely monocultural, are expanded, and they are able to experience and understand differences in meaningful and complex ways (Hammer, Bennett, \& Wiseman, 2003). Overall, studies examining CCEL are favorable and report that preservice teachers who participate in such programs generally increase their self-efficacy, cultural awareness, and professionalism (e.g. Batey \& Lupi, 2012, Clement and Outlaw, 2012; Cushner \& Mahon, 2002; Landerholm and Chacko, 2013, Lee, 2011, Marin, 2012; Marx and Moss, 2011; Pence \& Macgillvray, 2008; Quezada, 2004; Rodriguez, 2011; Sharam, Rahaza and Phillion, 2013; Thomas, 2012).

\section{CCEL HISTORY AND PROGRAMS}

Some credit the Fulbright Program (established in 1946) and the Peace Corps (established in 1961) with inspiring universities across the United States to encourage study abroad (Baker and Giacchino-Baker, 2000). The number of international field experiences offered by U.S. universities and colleges grew steadily from 1957 to the 1980s; and by the 1990s they had 
become widely accepted as "a way of preparing teachers to understand diversity” (Baker and Giacchino-Baker, 2000, p. 4). By the early 2000s over 100 universities participated or provided some type of student teaching abroad placement (Quezada, 2004). Today, multiple universities offer CCEL programs that vary widely from university to university in scope, format, and timeframe. Table 1 below highlights several published studies outlining programs that have been or are presently offered by universities in the United States.

Table 1

Examples of cross-cultural experiential learning programs

\begin{tabular}{|c|c|c|}
\hline Program/University & Location(s) & Highlights of Program Structure \\
\hline $\begin{array}{l}\text { Overseas Project at } \\
\text { Indiana University }\end{array}$ & $\begin{array}{l}\text { England, } \\
\text { Scotland, } \\
\text { Ireland, } \\
\text { Wales, } \\
\text { Australia \& } \\
\text { New Zealand }\end{array}$ & $\begin{array}{l}\text { preliminary coursework that includes } \\
\text { seminars, readings, workshops and } \\
\text { sessions with consultants from cultural } \\
\text { group } \\
\text { community involvement during } \\
\text { immersion student teaching } \\
\text { (Stachowski \& Mahan, 1998) }\end{array}$ \\
\hline $\begin{array}{l}\text { American Indian } \\
\text { Reservation Project } \\
\text { at Indiana } \\
\text { University }\end{array}$ & Navajo Nation & 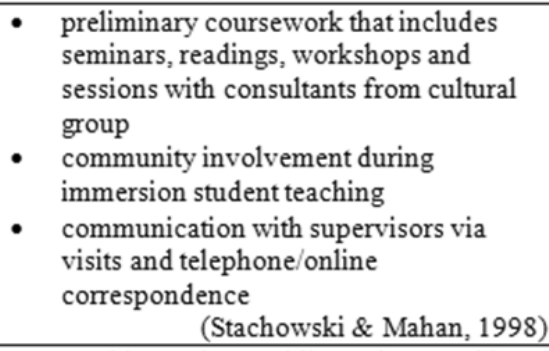 \\
\hline $\begin{array}{l}\text { Hispanic } \\
\text { Community Project } \\
\text { at Moorehead } \\
\text { University }\end{array}$ & $\begin{array}{l}\text { lower Rio } \\
\text { Grande Valley } \\
\text { (Texas) }\end{array}$ & $\begin{array}{l}\text { - weekly seminars while student teaching } \\
\text { - journals kept while student teaching } \\
\text { (Cooper, Bear, \& Thorman, 1990) }\end{array}$ \\
\hline $\begin{array}{l}\text { James Madison } \\
\text { University }\end{array}$ & $\begin{array}{l}\text { Italy, Wales, } \\
\text { Australia \& } \\
\text { Mexico }\end{array}$ & $\begin{array}{l}\text { - one credit seminar before traveling } \\
\text { - faculty member travels with preservice } \\
\text { teachers to assist with initial transition to } \\
\text { host country } \\
\text { (Pence \& Macgillvary, 2008) }\end{array}$ \\
\hline $\begin{array}{l}\text { Intemational } \\
\text { Internships at the } \\
\text { University of } \\
\text { Florida }\end{array}$ & England & $\begin{array}{l}\text { three week student teaching placement } \\
\text { abroad } \\
\text { - five meetings before traveling that cover } \\
\text { the pragmatics of intemational living and } \\
\text { work on creating teams between travelers } \\
\text { (Lupi \& Batey, 2009) }\end{array}$ \\
\hline $\begin{array}{l}\text { London Program at } \\
\text { the University of } \\
\text { Connecticut }\end{array}$ & $\begin{array}{l}\text { London, } \\
\text { England }\end{array}$ & $\begin{array}{l}\text { - semester-long cross-cultural experiential } \\
\text { leaming program } \\
\text { - "re-entry" seminar after retuming to the } \\
\text { United States } \\
\text { (Marx \& Moss, 2011) }\end{array}$ \\
\hline
\end{tabular}


Additionally, organizations and consortiums have been created and currently operate to assist schools of education in providing preservice teachers with CCEL student teaching opportunities. For example, the Consortium for Overseas Student Teaching (COST) is a collaboration of 15 colleges and universities and offers placements in over a dozen countries around the globe (COST, 2014). Likewise, Educators Abroad has placed student teachers from 142 universities in 77 countries (Educators Abroad, n.d.).

Although CCEL programs have many different forms, the overall body of research surrounding such coursework points favorably to this avenue of teacher education as a means of creating transformational learning experiences that challenge preservice teachers to reflect on their own ideologies. However, some studies do highlight challenges to CCEL. Jester and Finckel (2013) followed 53 preservice teachers to Alaska Native Village schools. Findings from this study indicated that the white preservice teachers felt empowered to use their position in the schools to teach the students about local Alaska Native languages and traditions, but they often applied a deficit model to student learning and did not employ culturally relevant pedagogies or curricula (Jester \& Fickel, 2013). Jester and Finckel (2013) reported that the preservice teachers were disconnected from the community-a problem of CCEL that Stachowski and Mahan (1995) recommended be mitigated by having preservice teachers live with host families during their teaching placement. They explain "as the relationship [with the host family] develops, information about respective cultures is shared, stereotypes are dissolved, and differences in lifestyles are examined and perhaps adopted" (Stachoweki and Mahan, 1995, p. 104). Other researchers have also acknowledged the tension that exists with the notion that that all preservice teachers will inherently and uniformly benefit from being placed in a context vastly different from their own (Anderson \& Stillman, 2013).

\section{CONCEPTUAL FRAMEWORK}

This research is positioned within and builds upon sociocultural theories of learning where knowledge is shaped by the social, historical and cultural contexts with rules and resources that mediate learners' experiences and understandings (Vygotsky, 1978). This stance stresses the importance of interactive participation between learners and their world (Vygotsky, 1997; Wertsch, 1991), taking into account the powerful influence that cultural practices have on the acquisition of knowledge (Gutierrez \& Rogoff, 2003).

\section{Whiteness Theory}

Whiteness theories, or whiteness studies, began in the late twentieth century at the intersection of white trash and critical race studies 
(Kennedy, Middleton \& Ratcliffe, 2005). However, while white trash studies try to place poor whites alongside poor nonwhites-thus ignoring the privileges afforded to whites in the United States-and critical race studies assert that social class is perceived differently between classes, whiteness studies seek to understand how whiteness functions as a social construct (Kenney, Middleton, \& Ratcliffe, 2005). White studies focus on the privileges bestowed on whites through the devaluation of nonwhites, as well the invisibility and normalization of whiteness (Thompson, 2001). Ruth Frankenburg (1997), a pillar in the field, deconstructs whiteness to three key components that intertwine to create the phenomenon:

First, whiteness is a location of structural advantage, of race privilege. Second it is a 'standpoint,' a place from which white people look at ourselves, at others, and at society. Third, 'whiteness' refers to a set of cultural practices that are usually unmarked and unnamed (p. 1). Thus, whiteness theory provides a lens to understand individuals' construction of their culture and personal position within their community and the society at large. While many (hooks, 1992; McIntyre, 1997; Morrison, 1992) support the view that white preservice teachers often "have little or no understanding of their own culture” (Ladson-Billings, 2001, p. 96), Winant (1997) argues that many whites do understand, at least to some extent, the privileges and power associated with whiteness. This paradox leaves issues of white privilege to be somewhat "thorny" for preservice teachers (Leland and Harste, 2005, p. 75) and thus creates tension for these prospective teachers within their identity construction (Winnat, 1997). For example, in their study of how one white preservice teacher negotiates cultural competence, Buehler et al. (2009) discovered a similar personal conflict: As their study participant developed awareness of her white privilege she simultaneously strove to downgrade its importance. The researchers explain, the preservice teacher feared "she couldn't be white and culturally competent as the same time” (Buehler, et al., 2009, p. 410).

Further, by examining cross-cultural experiential learning through the lenses of whiteness and sociocultural understandings of knowledge acquisition, the complexities of preservice teachers' experiences can be deconstructed. As preservice teachers grapple with the culture and social system they suddenly find themselves immersed in - presumably one vastly different from their own-they must recognize their whiteness while simultaneously learning new knowledge; knowledge that may conflict with their previous understandings of the world. Combined, these theories highlight the daunting internal struggle that many face when presented with situations that conflict with the ingrained practices of their own culture.

The data presented in this paper are drawn from a larger longitudinal study of the impact of cross-cultural experiential learning on teacher pedagogy. This larger study follows three student teachers, in a cohort of twenty-four, for two years before and after electing to spend nine 
of their required eighteen weeks of student teaching in western Uganda. The preservice teachers lived in a small university-owned house in the village of Kasese and traveled the forty minute commute (by car) daily to a small Christian school in Rwentutu, Uganda. For the present study one participant, Nora, was recruited because 1) she exemplifies the qualities (female, white, middle-class) of a large percentage of the teaching force currently teaching in U.S. schools and in teacher education programs (AACTE, 2009; Green et al. 2011); and, 2) she considers her time in Uganda to be "successful” based on her students' progress and the feedback she received. This later point was a crucial component to this study because, it could be argued that, student-teachers who do not consider their cross-cultural experience "successful" might not have been able to make meaning from their experience. Moreover, Nora was the only white female in her cohort to student teach in Uganda.

\section{METHOD}

The methodology of the study was influenced by narrative approaches, as well as sociocultural theories of learning where knowledge is gained through the co-construction of social and individual processes (Wertsch, 1991). This interpretive perspective is grounded in the idea that knowledge is "constructed in and out of interaction between beings and their world" (Crotty, 1998, p. 42). As Polanyi (1958) explains, knowledge must be integrated with personal knowing through "critical reflection on our own knowledge” (p. 373) [emphasis added]. Subsequently, through the construal of understandings and personal contemplation, "knowing" is individualistically shaped and realized.

Methods of narrative inquiry (Connelly \& Clandinin, 2000) were utilized for two reasons. First, the sociocultural lens, where knowledge is constructed from interaction with others and one's environment, lends itself to the construction of narratives between the storyteller and the researcher. Gubrium and Holstein (2009) acknowledge that "[n]arrative is framed as a social product, not as a social action” (p. xvi), indicating that stories told during narrative research are socially constructed and would change if the conditions and/or methodology of the research were augmented. Further, this methodology, as described by Clandinin (2013), builds upon the foundations put forth by John Dewey. Dewey understood that his experiences were important factors in his teaching pedagogy, and narrative inquiry gives voice to teachers' experiences and teacher knowledgeknowledge "that [is] personal, practical, shaped by, and expressed in practice” (Clandinin, 2013, p. 9). Because the methodology of narrative inquiry is 1) so innately connected to the theoretical perspective employed in this study, and 2) has foundations in the educational arena, it was a highly attractive methodological choice. 


\section{Data Collection}

For one academic year, as a university supervisor, Nora's stories of experience were gathered using several narrative inquiry approaches, including observations of her teaching, document collection, informal conversations, formal interviews, and the writing of field notes following interactions with Nora (Clandinin \& Connelly, 1994, 2000). Two classroom observations were conducted before Nora completed her CCEL, as well as four classroom observations upon her return to the United States. Notes from the classroom observations, as well as personal reflections about the lessons written by Nora, were collected. Document collection included end-of-semester evaluations of Nora's performance as a preservice teacher, an online blog kept by Nora during her time in Uganda, and Nora's application to student-teach in Uganda. And finally, two in-depth, semistructured interviews, spanning approximately three hours each, were conducted with Nora after she completed her teacher education program. Descriptive field notes of these interviews and the observations, as well as theoretical memos (Creswell, 2013), were also used as data sources for this study.

\section{Data Analysis}

Throughout the data collection, documents and transcripts were continuously reread and notes/memos were made as a means of exploring the data (Creswell, 2013). The data then underwent a series of two phases of coding. Initially, descriptive coding (Saldana, 2013, p. 105) was employed and basic themes were created to analyze the topics of the data. During this cycle of coding, chunks of data were coded based on content. For example, Nora's concerns about student teaching in Uganda, before the trip began, became one code. Another code centered on Nora's interactions with students. After these codes were created, pattern codes were generated from the themes that emerged in this first cycle (Saldana, 2013). Pattern coding, similar to thematic analysis, focuses "on what is said, rather than how, to whom, or for what purposes" [emphasis added] in order to interpret the data-a widely utilized and accepted approach to narrative analysis (Kohler Riessman 2008, p. 53-55). Pattern codes that developed during this second round of coding included: reflexivity, critical questioning, purpose of education, learning, culture, attitude, social justice, flexibility, self-reflection, and cultural dissonance (i.e., culture shock). All the data was then recoded using the new "second cycle" pattern codes (Saldana, 2013). Finally, from these two rounds of exhaustive coding, three themes surrounding Nora's meaning making surfaced from the data: flexibility, critical questioning, and self-reflection. These themes are presented and discussed below. 


\section{FINDINGS}

Informed by sociocultural learning and whiteness theories, as well as Ruth Frankenburg's (1997) outline of the critical components to whitenessprivilege, ideology, and cultural practices-Nora's stories of experience (Clandini \& Connelly, 1990) uncover how she was able to make meaning of her journey teaching and learning halfway around the world.

\section{Privilege}

Nora describes her childhood from birth until she entered high school as continuously changing and uncertain. She recounts moving over twenty times as a child, as well as being in seven hurricanes, including Hurricane Ivan at the age of twelve, at which time, she and her family lived without electricity for three weeks. From this early nomadic lifestyle, Nora concluded that she understood what it felt like to be an "outsider" early on-as she was accustomed to being the "new kid" and having to make new connections with friends and mentors (personal communication, June 16, 2014). Nora hypothesized that this constant upheaval in her childhood allowed her to become flexible, as she realized early on that she had little control over her environment and what happened around her.

When Nora began high school, her world became more stable and she lived in a small, wealthy suburb where she attended the same high school for three consecutive years. Nora described her town as "conservative" and estimated that 85 percent of her high school was comprised of white students (personal communication, June 16, 2014). But even in this environment, Nora still felt as though she was an outsider and didn't belong because, although she lived in an affluent neighborhood, as Nora explained, her family resided in an area with "less nicer houses" [sic] (personal communication, June 16, 2014). While Nora was unable to see the privileges she held by living in a wealthy suburb, this experience positioned her as different from her peers. Thus, Nora understood what it was like to be on the outside of a social group as well as how to enact multiple identities to homogenize to her surroundings.

In Uganda, Nora was confronted with the privileges she unconsciously enjoyed in the United States. In a conversation with a Ugandan teacher, the same teacher in the excerpt from Nora's blog at the onset of this paper, Nora was asked, "Do you like Africans?” (personal communication, February, 2014). Nora was thrown by this question because she felt that she obviously liked Africans if she traveled to Uganda to student teach. The Ugandan teacher then explained that some volunteers who travel to their villages do not take the opportunity to get to know the people; they simply do their work, read in their free time, and leave. The teacher continued by asking Nora why she and the other American teachers didn't stay in Rwentutu like the Ugandan teachers. Before Nora could 
answer, the teacher proclaimed, “Ah I know. There's no electricity here and it gets very dark at night" (Nora, personal communication, February 2014). After this interaction, Nora reflected in a blog post, "She implied that we were too good for this simplicity, and guilt set in...It was awful to realize that while I thought I was being open to stepping outside my comfort zone, I was still within a wider comfort zone" (personal communication, February, 2014). This conversation forced Nora to acknowledge that her status as a white American continued to serve her even when she felt as though she had left the comforts of home behind; something that she did not see until it was pointed out to her by a Ugandan teacher.

Additionally, early on in her student teaching, Nora was frustrated because during the first few days of school in Rwentutu, the students were in the classrooms "ready to learn," but the teachers were nowhere to be found (personal communication, February, 2014). Upon further probing, Nora learned that the teachers were busy registering and interviewing students for grade placement. While Nora accepted this answer, she problematized the situation, asking why registration and interviewing didn't take place before the start of the school year. The school bursar and "house mother" for the student teachers explained that parents can bring their children to the school for early registration and interviews, but many did not have the money for the child(ren) to travel to the school twice in such a short period of time; instead, they just sent them at the start of the school year. This caused a delay in when instruction could actually begin because teachers were busy with administrative duties. After this conversation, Nora confessed, "I felt so stupid. I hadn't even considered that his would be an issue” (personal communication, February, 2014). Yet again, Nora had come face-to-face with privileges that she had never before considered. To Nora, the easy solution was to have students register before the school year, because that is what would have happened in her community, but she hadn't realized the hardship this would cause families.

\section{Ideology}

Although Nora was unable-or simply did not exhibit in any of the data collected-to understand how her positionality influenced her selfperception, she did reveal signs that her view of the world was influenced by critical questioning and reflexivity. First, in her application to teach abroad, Nora questions the labels given to countries such as Uganda, as well as the purposes of education around the world. Nora states:

...I would like to investigate the effects that the United States' form of education has had on an 'underdeveloped' country such as Uganda. First, when Uganda is referred to as 'underdeveloped,' what is that saying? Does it mean it should follow the United 
States' trail to industrialization, computerization, and economic wealth, and if it is not, it is somehow inferior? (personal communication, July 14, 2014)

However, while Nora questioned the role of education around the world and the influence the United States has on other countries, she also brought her personal ideology of education to Rwentutu. Nora struggled with the high-stakes testing structure of education in Uganda-where students must pass a national exam in order to advance to the next level of schooling. Because of this, teachers and students focus on rote memorization of facts and charts. In a blog post, Nora discusses her frustration with students' inability to ask critical questions or even understand what the word 'wonder' means (personal communication, February, 2014). While it is not ideologically important to Ugandans to ask questions or critically scrutinize information presented to them, Nora felt as though she was doing a disservice to her students if she did not awaken them to these pedagogies.

Conversely, Nora understood how others may view her time in Africa as "charitable," yet she viewed the time as an opportunity to understand the "deep culture" of Uganda, as well as uncover what "lies at the heart of education" (personal communication, July 14, 2014). Here, Nora acknowledges the "commodification of humanitarianism in Africa" (Daley, 2013, p. 375) but seeks to distance herself from these selfpromoting motivations behind traveling and working in third world countries. Furthermore, in Nora's final blog post before returning to the United States, she comments on American culture, noting, "I am a product of our emphasis on individuality and personal freedoms" and "There is no greater patriotism than recognizing the faults in [your] country's fabric and working tirelessly to mend them” (personal communication, April, 2014). From these statements, as well as those above, it is reasonable to conclude that Nora was able to see and question the ideologies of the United States, but she was unable to view her own beliefs as problematic or ideological. For Nora, her personal views were simply her opinion of how things should be, not something she needed to critically examine.

\section{Cultural Practices}

During the interviews, Nora made numerous references to the time she spent attending and volunteering in a Chinese-American Christian Church while in high school. Nora explained that while she was at the church she felt as though she had to navigate the emotions and isolation associated with being a "cultural outsider" (personal communication, June 16, 2014). This was a very transformation experience for Nora and allowed her to "find similarities with people that you initially think are different" (personal communication, June 16, 2014). Because of this experience, 
Nora noted that while she was in Uganda, she had to build authentic relationships with Ugandans as a means of understanding their cultural practices and to become an "insider."

However, reflecting upon cultural practices, either American or Ugandan, was difficult for Nora before traveling abroad, as well as during her first few weeks in Uganda. While she did not attempt to juxtapose the two cultures, there was often some comparison between them in her blog entries. For example, within her school and position as a teacher in Rwentutu, Nora was often critical of the culture of education in Uganda. She found it difficult to teach in an educational system that did not value critical thinking. Additionally, Nora was very alarmed at and upset by Ugandans' cultural practice of killing wrongdoers. For example, from Nora's experience in Uganda, it was commonplace for drivers who caused what we call in the United States "vehicular manslaughter" to be put to death (personal communication, June 16, 2014). As a means of merging these two practices that were inconsistent with her own customs, Nora organized a debate for her students regarding the issues involved in capital punishment. After her students participated in the debate, Nora noted:

[The students] are entitled to their own opinions, but I found many contradictions and flaws in their logic, so I wanted to hash those out. I don't believe that teachers indoctrinate students or push their own beliefs as unquestionably right, but I think they should encourage moral development, because even though there are no right answers in life, there are more advanced arguments and levels of thinking. (personal communication, March, 2014)

While it seems clear that Nora was not trying to "push" her values onto the students, she did make a judgement about the Ugandan culture. What is also interesting is that when asked what her biggest achievement was while teaching in Rwentutu, Nora stated that she was proud of getting the students to think critically and for themselves (personal communication, June 16, 2014). Nora did not recognize that she was prioritizing the white middle-class conception of "good teaching" over how Ugandans traditionally educate and are educated.

Yet again, while Nora had difficulty seeing her own favoritism toward Western customs, she was critically aware of the behavior of white Westerners as a whole. During one interview, Nora expressed frustration that before departing for Uganda, no one at her home university told the student teachers that Ugandans, in cities and in villages, dress rather formally (personal communication, June 16, 2014). The Americans, herself included, dressed in lighter clothing, with casual shirts, usually made of some type of khaki material, and wore sporty sandals. Nora worried that dressing in this manner while visiting the same places as Ugandans, who 
were dressed in business attire, signaled that Americans thought of their time in Africa as "one big safari-vacation" (personal communication, June, 2014).

When she returned to student teaching in the United States, Nora was markedly more aware of the cultural disconnect her students faced at school and in her own classroom. Before student teaching abroad, Nora's lesson plans and post-lesson reflections did not explicitly consider her students' cultural heritage. While Nora worked diligently to create interesting student centered lessons, it could be concluded that she selected themes, texts, and multimedia that were interesting to her and just assumed these would also be interesting to her racially, culturally and socioeconomically diverse students. However, upon returning from Uganda, Nora attempted to integrate various cultural practices and interests of the students into her overall teaching and lessons. For example, the notion of raising one's hand is, arguably, a white middle-class norm that is forced upon students of all cultures and classes in PK-12 classrooms throughout the United States. Nora, however, after returning from student teaching abroad, alternated between requiring students to raise their hand to speak (signed by such statements as, "Can anyone raise their hand and tell me....) with allowing students to simply call out an answer (classroom observation, May 9, 2014). Further, upon her return from Uganda, Nora became more aware of her students' interests and began to employ them as a means of increasing their engagement. This was best illustrated when Nora, teaching a seventh grade mathematics unit on "data distribution," challenged students to analyze the interactive multimedia graph, "The Largest Vocabulary in Hip Hop” (classroom observation, May 20, 2014). While Nora understood that not all of her students listened to rap or hip hop music, she knew from interacting with the students and from interest surveys that this genre was appealing to many. When later discussing her planning decisions, Nora explained that while in Uganda she realized the lack of students' culture in U.S. schools in which she had previously worked (personal communication, June 16, 2014). Nora concluded that by integrating more culturally relevant practices and material she could honor students' backgrounds and knowledge, as well as minimize some of the "behavior issues" that took place in many classrooms (personal communication, June 16, 2014).

\section{DISCUSSION}

Though Nora, before traveling to Uganda, was not completely aware of the privileges she enjoyed, the socially accepted ideologies, or the cultural practices of whiteness, it can be argued that she was more cognizant of these than the typical white, middle-class female in their early twenties (Hartmann, Gerteis, Croll, 2009). Because of this, Nora was able to exploit 
her stories of experience (Clandinin and Connelly, 1990) as a means of reflecting upon her personal knowledge of whiteness to construct significant understandings from her interactions while student teaching abroad, as well as employ these new understandings to classroom teaching upon returning to the United States. However, as the findings above also indicate, this does not mean that Nora was able to completely understand her own whiteness, as well as the privileges, ideologies and cultural practices that accompany whiteness, while in Uganda.

First, while abroad, Nora drew only minimally on her stories of experience (Clandinin and Connelly, 1990). For example, though Nora noted that she felt as though she was a "cultural outsider" while working in the Chinese-American Christian Church because of the differences in cultural practices between most of the church congregation and her own upbringing, she did not actually employ this experience of being a cultural outsider while in Uganda. Instead, it seemed as though Nora made hasty judgements about situations based on her own cultural background in the United States. However, when Nora was confronted with her ideologies, such as when the Ugandan teacher asked her why the preservice teachers didn't say in Rwentutu, or when she challenged the start date of instruction, Nora was able to reflect on her assumptions and beliefs as a means of understanding the Ugandans' perspectives, culture and ways of being.

Additionally, though Nora critically questioned Western practices and assumptions, such as the lack of attention her university paid to the formal dress in Uganda or the notion that Uganda is "underdeveloped" and the United States is "developed," she did not critically question her own ideologies. This can be seen in Nora's desire, ironically, to get the Ugandan students to question their world-a privilege and ideology employed and enjoyed in educational institutions around the United States. Nora, however, never thought about how and why her stance toward this style of teaching was culturally different from the teaching styles traditionally found in Ugandan schools. To Nora, many of her own ideals about teaching and learning, as well as what is just and fair, were simply correct and did not need examination. Overall, Nora was unable to see her own whiteness - her privileges, ideologies and cultural practices-while in Uganda, but she was able to employ some reflexivity and critical questioning when her ways of knowing were pressed or when they collided with others' assumptions.

Conversely, while Nora did not fully utilize her skills, dispositions and knowledge of whiteness while in Uganda, she did capitalize on her experiences abroad upon returning to the United States, when student teaching a diverse group of middle school students. As described above, Nora employed culturally relevant pedagogies, as well as capitalizing on students' various funds of knowledge, during student teaching observations following her time in Uganda. In interviews, Nora even noted that her time 
abroad prompted her to reflect on teaching diverse students and how, she felt, the school in the United States that she would finish her student teaching in, did not honor student diversity. This realization on Nora's part allowed her to embrace her whiteness and understand how the privileges afforded to her, as well as the ideologies and cultural practices of whiteness, can alienate her students.

\section{IMPLICATIONS FOR PRACTICE}

The purpose of cross-cultural experiential learning is to submerse students in a culture different from their own so that they can experience the dissonance that accompanies the navigation of foreign systems and traditions. For Nora, her time in Uganda was her first encounter with being marked as different because of her whiteness. When first arriving in Uganda, Nora noted, "I have never felt so blatantly different from others before" (Nora, personal communication, January, 2014) and that she would never again take for granted interactions with people within her own culture (personal communication, April, 2014). It is evident that Nora's time in Uganda highlighted for her the normalization of whiteness in the United States. In this respect, Nora's trip was successful in that she is now able to empathize with students forced to conform to a hegemonic society and educational system, a finding that echoes the numerous researchers and teacher educators who have also concluded that cross-cultural experiential learning is a means of positive transformation and reflective learning among preservice teachers. However, adequately preparing our predominantly white and middle-class teaching force to teach the diverse PK-12 student populations in $21^{\text {st }}$ century classrooms (NCES, n.d.) through CCEL alone is not enough: We must also earnestly consider how to facilitate these potentially transformative learning opportunities before, during, and after students travel abroad so that all preservice teachers participating in such experiences are able come away with meaningful learning that translates into real classroom change. As such, two suggestions are offered to provide academic institutions, facilitating professors, and offices charged with organizing study abroad programs approaches in assisting study abroad students with the internal processing of their experiences.

First, students who are abroad, and more specifically students who are conducing preservice teaching abroad, should have intensive coursework before and after participating in their program-a model followed in whole or part by many universities that offer successful CCEL programs (e.g., Cooper, Beare, \& Thorman, 1990; Marx \& Moss, 2011; Stachowski \& Mahan, 1998; Vail \& Tennion, 1992). Courses before traveling abroad can include seminars, readings, workshops and sessions with consultants from the cultural group students will be living with, as 
well as experiences to assist students in understanding their whiteness and the privileges, ideologies and cultural practices that accompany whiteness (Frankenburg, 1997). Additionally, students should be educated on a model of cultural dissonance. In his model, Oberg (1960) explains that cultural dissonance (i.e., culture shock) is brought on by the anxiety that is felt when the proverbial "rule book of meanings" no longer exists (Marx \& Moss, 2011). Researchers acknowledge that an understanding of cultural dissonance has the potential to spark transformative learning and assist students in working through their culture shock (e.g., Marx \& Moss, 2011; Vail \& Tennion, 1992; Winkelman, 1994). Finally, once students return from studying abroad, it is vital that they participate in a re-entry program/course to support them in re-acclimating to their home community, as well as processing their experiences and unpacking their changing ideologies and beliefs. While all of these courses can vary in length, it is vital that university personnel work with individual students for as long as each needs-as failure to do so may intensify students' feelings of loneliness, anxiety or misunderstandings of cultures other than their own.

Second, and perhaps more vital than facilitating coursework before and after students travel abroad, is the coursework and/or continual twoway communication students need with facilitating university professors during their program. Ideally, this work would be done in person, either by having a course facilitator working with students while abroad, or by having students' home university professors traveling to meet the students at least once during their program. However, since financial and time constrictions often prohibit these types of interactions, technology can be employed to allow students and professors to engage in meaningful dialogue. Through emails, blogs, telephone calls and applications such as Skype, professors can assist students in working through their cultural dissonance, as well as in grappling with transformative learning. Additionally, it is imperative that students keep reflective journals during their experience, which also can be utilized during re-entry programs to stimulate conversations and aid students in remembering their initial feelings and experiences. Journal entries can also act as a means of facilitating discussion between students and professors. Overall, the purpose of "during program" coursework and/or communication is to be a catalyst for student reflection and transformative learning.

\section{IMPLICATIONS FOR FURTHER RESEARCH}

The purpose of this study was to better understand how one female, white, middle-class preservice teacher made meaning from student-teaching in a remote village in western Uganda. While the data and results presented here are not generalizable, they are meant to further propel the study of 
cross-cultural experiential learning programs for preservice educators. Some further questions resulting from the current study include:

- How do student teachers' dispositions prior to cross-cultural student-teaching impact their experience?

- Should whiteness theory be taught within the multicultural context of teacher education programs?

- Do student teachers who have prior experience as an "outsider" make meaning of cross-cultural student teaching differently from those student teachers who do not?

- How do student teachers of various racial groups make meaning of the same cross-cultural experience?

- What role does the university play in assisting student teachers in the process of meaning making?

Gloria Landson-Billings (2001) suggests that it is new teachers, not policies, which are central to creating equitable schooling practices. Therefore, it is the duty of teacher education programs to educate preservice teachers to close the cultural gaps that exist between teachers and the students that sit before them. Cross-cultural experiential learning has been found to be an effective means of closing these gaps, by many aforementioned researchers, as well as in this study. Another avenue of teacher education that has emerged from the present research is the role that understanding whiteness and white theory have on the multicultural education of preservice teachers.

\section{REFERENCES}

Alfaro, C., \& Quezada, R. L. (2010). International teacher professional development: Teacher reflections of authentic teaching and learning experiences. Teaching education, 21 (1), 47-59.

Anderson, L. M., \& Stillman, J. A. (2013). Student Teaching's Contribution to Preservice Teacher Development A Review of Research Focused on the Preparation of Teachers for Urban and High-Needs Contexts. Review of Educational Research, 83(1), 3-69.

Banks, J., Cochran-Smith, M., Moll, L., Richert, A., Zeichner, K., LePage, P., ... \& McDonald, M. (2005). Teaching diverse learners. Preparing teachers for a changing world: What teachers should learn and be able to do, 2005, 232-274.

Batey, J. J., \& Lupi, M. H. (2012). Reflections on interns' culture developed through a short-term international internship.” Teacher Education Quarterly 39 (3), 25-44.

Buehler, J., Ruggles Gere, A., Dallavis, C., \& Shaw Haviland, V. (2009). Normalizing the fraughtness: How emotion, race, and social school context complicate cultural competence. Journal of Teacher Education, 60, 408-418.

Burbank, M., Ramirez, L., Bates, A. (2012). Critically reflective thinking in urban teacher education: A comparative case study of two participants' experiences as content area teachers. The Professional Educator, 36 (2).

Clandinin, D. J. \& Connelly, F.M. (1990). Stories of experience and narrative inquiry. Educational Researcher, 19, p. 2-1 
Clandinin, D.J. \& Connelly, F. M. (1994). Teacher's professional knowledge landscapes: teacher stories-stories of teachers-school stories-stories of schools. Educational Researcher, 25 (3), p. 24-30.

Clandinin, D. J. (2013). Engaging in Narrative Inquiry. Walnut Creek, CA: Left Coast Press Incorporated.

Clement, M. C., \& Outlaw, M., E. (2012). Student teaching abroad: learning about teaching, culture, and self.” Kappa Delta Pi Record 38 (4), 180-183.

Cochran-Smith, M. (2010). Toward a theory of teacher education for social justice. In M. Fullan, A. Hargreaves, D. Hopkins, \& A. Lieberman (Eds.), International handbook of education change (2nd ed, pp. 445e467). New York, NY: Springer.

Cochran-Smith, M., \& Zeichner, K. M. (2005). Studying teacher education: The report of the AERA Panel on Research and Teacher Education. Mahwah, N.J: Lawrence Erlbaum Associates.

Connelly, F. M., \& Clandinin, D. J. (2000). Narrative inquiry: Experience and story in qualitative research. Jossey-Bass: San Francisco.

Consortium for Overseas Student Teaching (COST). (2014, November 12). Retrieved from http://www.gvsu.edu/cost/.

Cooper, A., Beare, P., \& Thorman, J. (1990). Preparing teachers for diversity: A comparison of student teaching experiences in Minnesota and south Texas. Action in Teacher Education, 12 (3), 1-4.

Creswell, J. W. (2013). Qualitative inquiry and research design. Choosing among five approaches. Third edition. Thousand Oaks: Sage Publications.

Crotty, M. (1998). Foundations of social research: Meaning and perspective in the research process. Thousand Oaks: Sage Publications.

Cushner, K., \& Brennan, S. (2007). The value of learning to teach in another culture.” In Intercultural student teaching: A bridge to global competence, edited by $\mathrm{K}$. Cushner and S. Brennan, 1-11. Lanham, MD: Rowman Littlefield.

Cushner, K., \& Chang, S. C. (2015). Developing intercultural competence through overseas student teaching: Checking our assumptions. Intercultural Education, 26 (3), 165178.

Cushner, K., \& Mahon, J. (2002). Overseas student teaching: Affecting personal, professional, and global competencies in an age of globalization. Journal of Studies in International Education, 6, 44-58.

Daley, P. (2013). Rescuing African bodies: celebrities, consumerism and neoliberal humanitarianism. Review of African Political Economy, 40(137), 375-393.

Educators Abroad. (n.d.). Retried from https://educatorsabroad.org/home/

Foote, C. J., \& Cook-Cottone, C. P. (2004). Field experience in high-need, urban settings: Analysis of current practice and insights for change. The Urban Review, 36 (3), 189-210.

Frankenberg, R. (1993). White women, race matters: The social construction of whiteness. Minneapolis, MN: University of Minnesota Press.

Freeman, G., Izzard, M., Faulkner, R., \& Charles, J. (2012). University School of Education Promoting Diversity Awareness and Initiatives. Professional Educator, 36(1), 1-7.

Gay, G. (1997). Educational equality for students of color. In J. A. Banks \& C. A. M. Banks (Eds.), Multicultural education: Issues and perspectives (pp. 195-228). Boston: Allyn \& Bacon.

Gay, G., \& Howard, T. C. (2000). Multicultural teacher education for the 21st century. The Teacher Educator, 36(1), 1-16.

Grant, C. A. (1994). Best practices in teacher preparation for urban schools: Lessons from the multicultural teacher education literature. Action in Teacher Education, 16 (3), $1-18$.

Green, A. M., Kent, A.M., Lewis, J., Feldman, P., Motely, M.R., Vitulli Baggett, P., Shaw Jr., E.L., Byrd, K., \& Simpson, J. (2011). Experiences of elementary pre-service 
teachers in an urban summer enrichment program. The Western Journal of Black Studies, 35 (4), 227-239).

Gubrium, J. F. \& Holstien, J. A. Analyzing Narrative Reality. Thousand Oaks: Sage Publications

Hammer, M. R., Bennett, M. J., \& Wiseman, R. (2003). Measuring intercultural sensitivity: The intercultural development inventory. International journal of intercultural relations, 27(4), 421-443.

Hartman, D., Gerteis, J., \& Croll, P. R. (2009). An empirical assessment of whiteness theory: Hidden from how many? Social Problems, 56(3), p. 403-424.

hooks, b. (1992). Representing Whiteness in the Black imagination. In R. Frankenberg (Ed.), Displacing Whiteness: Essays in social and cultural criticism (pp. 165-179). Durham, NC: Duke University Press.

Jester, T. E., \& Fickel, L. H. (2013). Cross-cultural field experiences in Alaska native villages: Implications for culturally responsive teacher education. The Teacher Educator, 48(3), 185-200.

Kennedy, T. M., Middleton, J. I. \& Ratcliffe, K. (2005). The matter of whiteness: Or, why whiteness studies is important to rhetoric and composition studies. Rhetoric Review, 24(4), p. 359-373.

Kennedy, A. S., \& Heineke, A. J. (2016). Preparing Urban Educators to Address Diversity and Equity through Field-Based Teacher Education: Implications for Program Design. Handbook of Research on Professional Development for Quality Teaching and Learning, 437.

Kissock, C., \& P. Richardson. (2010). Calling for action within the teaching profession: It is time to internationalize teacher education. Teaching Education 21 (1), 89-101.

Kohler Riessman, C. (2008). Narrative Methods for the Human Sciences. Thousand Oaks: Sage Publications.

Ladson-Billings, G. (2001). Crossing over to Canaan: The journey of new teachers in diverse classrooms. San Francisco: Jossey-Bass.

Landerholm, E., \& J. Chacko. (2013). Student teaching abroad: An experience for 21st Century teachers. ERIC - Institute of Education Sciences: Washington, DC.

Lee, J. (2011). International field experiences - What do student teachers learn? Australian Journal of Teacher Education 36 (10), 1-21.

Leland, C. H., \& Harste, J. (2005). Doing what we want to become: Preparing new urban teachers. Urban Education, 40(1), 60-77.

Lu, H. \& Soares, L. B. (2013, April). Lessons learned from an international pilot study: Preservice teachers' experiences in teaching students in Taiwan. Paper presented at the American Educational Research Association Annual Meeting, San Francisco, CA.

Mahan, J. M. \& Stachowski, L. (1990). New horizons: Student teaching abroad to enrich understanding of diversity. Action in Teacher Education, 12 (3), 13-22.

Malewski, E., Sharma, S, \& Phillion, J. (2012). How international field experiences promote cross-cultural awareness in preservice teachers through experiential learning: Findings from a five year collective case study. Teachers College Record 114(8), $1-44$.

Martin, L. C. (2012). International student teaching in non-western cultures: Impact on first-year teachers. (Unpublished doctoral dissertation). Iowa State University, Ames, IA.

Marx, H. \& Moss, D. M. (2011). Please mind the gap: Intercultural development during a teacher education study abroad. Journal of Teacher Education, 62 (1), 35-47.

McDonald, M. Tyson, K., Brayko, K., Bowman, M., Delport, J., Shimomura, F. (2011). Innovation and impact in teacher education: Community based organizations as field placements for preservice teachers. Teachers College Record, 113(8).

McIntyre, A. (1997). Making meaning of Whiteness: Exploring racial identity with White teachers. Albany, NY: State University of New York Press. 
Morrison, T. (1992). Playing in the dark: Whiteness and the literary imagination. Cambridge, MA: Harvard University Press.

National Center for Education Statistics (NCES), U.S. Department of Education. (n.d.). Number and percentage of teachers in public and private elementary and secondary schools, by selected teacher characteristics: Selected years, 1987-88 through 2011-12. Digest of Education Statistics. Retrieved from https://nces.ed.gov/programs/digest/d13/tables/dt13_209.10.asp

Oberg, K. (1960). Cultural shock: Adjustment to new cultural environments. Practical Anthropology, 7, 177-182.

Ochoa, A. 2010. International education in higher education: A developing process of engagement in teacher preparation programs. Teaching Education 21 (1),103-112.

O'Connor, M. (1993). On the misadventures of capitalist nature. Capitalism Nature Socialism, 4(3), 7-40.

Pence, H. M., \& Macgillvray, I. K. (2008). The impact of an international field experience on preservice teachers. Teaching and Teacher Education, 24 (1), 14-25.

Polanyi, M. (1958). Personal knowledge: Towards a post critical philosophy. Chicago: University of Chicago Press.

Quezada, R. L. (2004). Beyond educational tourism: Lessons learned while student teaching abroad. International Education Journal, 5 (4), 458-465.

Rodriguez, E. (2011). What pre-service teachers bring home when they travel abroad: Rethinking teaching through a short international immersion experience. Scholar Practitioner Quarterly 5 (3), 289-305.

Rust, F. (2010). Shaping new models for teacher education. Teacher Education Quarterly, 5-18.

Saldana, J. (2013). The coding manual for qualitative researchers. Second Edition. Thousand Oaks, CA: Sage Publications.

Sharma, S., Rahatzad, J., \& Phillion, J. (2013). How pre-service teachers engage in the process of (de)colonization: Findings from an international field experience in Honduras. Interchange 43, 363-377.

Sleeter, C. E. (2001). Preparing teachers for culturally diverse schools: research and the overwhelming presence of whiteness. Journal of Teacher Education, 52, 94-106.

Stachowski L. L. \& Frey C. J. (2003). Lessons learned in Navajoland: Student teachers reflect on professional and cultural learning in reservation schools and communities. Action in Teacher Education, 25(3), 38-47.

Stachowski, L.L., \& Mahan, J.M. (1995). Learning from international field experiences. In G.A. Slick (Ed.), Emerging trends in teacher education: The future of field experiences (Vol. 4; pp. 99-107). Thou- sand Oaks, CA: Corwin Press.

Stachowski, L. L., \& Mahn, J. M. (1998). Cross-cultural field placements: Student teachers learning from schools and communities. Theory into Practice, 37 (2), 155-162.

Thomas, S. (2012). The influence an overseas teaching experience has on teaching decisions. (Unpublished doctoral dissertation). Boston University, Boston, MA.

Thompson, A. (2001). Summary of whiteness theory. Retrieved from http://www.pauahtun.org/Whiteness-Summary-1.html

Veil, N. G. \& Tennison, J. M. (1992). International student teaching: Stimulus for developing reflective teachers. Action in Teacher Education, 13 (4), 31-36.

Voltz, D. L. (1998). Challenges and choices in urban education: The perceptions of teachers and principals. The Urban Review, 30 (3), 211-228.

Walters, L. M., Garii, B, \& Walters, T. (2009). Learning globally, teaching locally: Incorporating international exchange and intercultural learning into pre-service teacher training. Intercultural Education 20, S151-S158.

Wertsch, J. V. (1991). A sociocultural approach to socially shared cognition. In L. B. Resnick, J. M. Levine, \& S. D. Teasley (Eds.), Perspectives on socially shared cognition (pp. 85- 100). Washington, DC: American Psychological Association 
Whipp, J. L. (2013). Developing socially just teachers: The interaction of experiences before, during, and after teacher preparation in beginning urban teachers. Journal of Teacher Education, 64, 454- 467.

Wilson, A. H. (1982). Cross-cultural experiential learning for teachers. Theory into Practice, 21 (3), 184-192.

Wilson, S., Floden, R., \& Ferrini-Mundy, J. (February, 2001). Teacher Preparation Research: Current Knowledge, Gaps, and Recommendations. Center for the Study of Teaching and Policy, University of Washington, WA.

Winant, H. (1997). Behind blue eyes: Whiteness and contemporary U. S. racial politics. In M. Fine, L. Weis, L. C. Powell, \& L. M. Wong (Eds.), Off White: Readings on race, power, and society (pp. 40-53). New York: Routledge.

Winkleman, M. (1994). Cultural shock and adaptation. Journal of Counseling and Development, 73, 121-126.

STEPHANIE J SHEDROW is a PhD candidate at the University of Wisconsin, Madison in the department of Curriculum and Instruction with foci in literacy, teacher education, educational policy and qualitative research. Her research interests include assessment practices and home/school connections. E-mail: shedrow@wix.edu 